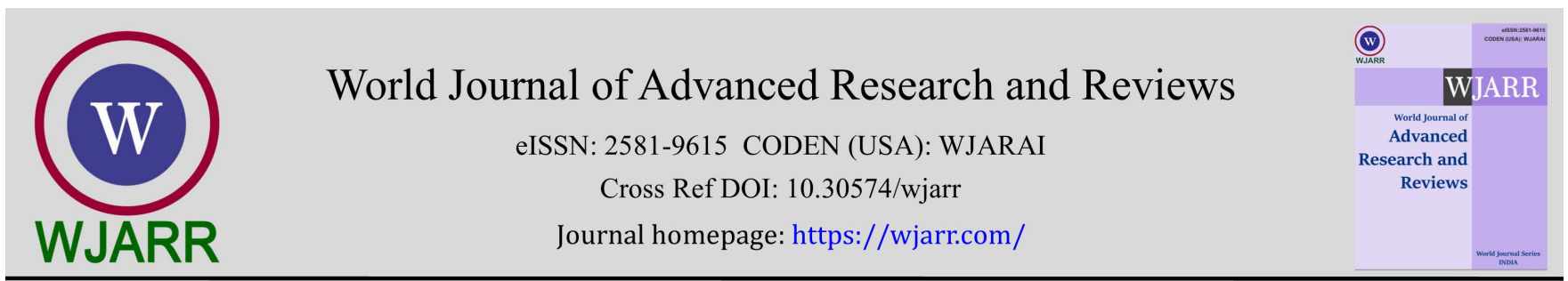

(RESEARCH ARTiClE)

Check for updates

\title{
Allelopathic effects of Amaranthus viridis L. on germination and growth of Eruca
}

\section{sativa L.}

\author{
Misson Fathal- rahman Osman and Elnasri Mohamed Mutwali * \\ Department of Biology, Faculty of Education, Alzaiem Alazhari University, Sudan.
}

World Journal of Advanced Research and Reviews, 2022, 13(02), 316-319

Publication history: Received on 07 January 2022; revised on 12 February 2022; accepted on 14 February 2022

Article DOI: https://doi.org/10.30574/wjarr.2022.13.2.0149

\begin{abstract}
A pot experiment was conducted at Alzaiem Alazhari University during 2020/2021 to study the effect of Amaranthus viridis powder incorporated into the soil on germination and growth of garden rocket (Eruca sativa). The experiment was arranged in completely randomized design (CRD) with four replicates. Five concentrations $(0,0.5,1.0,1.5$ and $2.0 \%$ w/w) on basis of Amaranthus viridis powder incorporated in the soil. Results indicated that Amaranthus viridis powder decreased germination, shoot length, leaf area, shoot and root fresh and dry weight as well as chlorophyll content and some chemical elements (P, Ca, Mg, Fe).
\end{abstract}

Keywords: Amaranthus; Garden rocket; Germination; Allelopathy; Chlorophyll content

\section{Introduction}

Weeds are one of the worst biological constraints to increase crop production and if left uncontrolled cause massive yield losses in field crops. Weeds growing with crops interact with each other and exert inhibitory effects on each other through releasing compounds known as allelochemicals. These allelochemicals affect other plants at their germination and seedling growth. Allelopathic effects of weeds on emergence and growth of crops have been documented [1,2].

Garden rocket (Eruca sativa) is a leafy vegetable predominantly eaten raw. It is rich in vitamin C and important powerful antioxidant and it is cancer-fighting food [3]. Garden rocket is cultivated in large areas in Khartoum, Sudan and is one of the daily food consumed by most of Sudanese people. However, the production of garden rocket is not stable as weeds compete with it and reduce the yield.

Amaranthus viridis is an annual verb distributed throughout the world especially tropical countries. It has been reported as a principal and troublesome weed of corn (Zea mays L.), sugarcane (Saccharum officinarum L.), sorghum (Sorghum bicolor L.) and vegetables [4]. Amaranthus viridis is one of the most noxious weeds that imposed the garden rocket production. It is found grown in cultivated lands, canal banks and the bank of the Blue Nile and White Nile in Khartoum. Therefore the present work was conducted to evaluate the negative effect of Amaranthus viridis on the germination and growth of garden rocket.

\footnotetext{
${ }^{*}$ Corresponding author: Elnasri Mohamed Mutwali

Department of Biology, Faculty of Education, Alzaiem Alazhari University, Sudan.

Copyright $(2022$ Author(s) retain the copyright of this article. This article is published under the terms of the Creative Commons Attribution Liscense 4.0.
} 


\section{Material and methods}

\subsection{Plant material}

Amaranthus viridis plants was collect from Shambat area, Faculty of Agriculture, University of Khartoum. The plants were uprooted, washed with distilled water, then dried at room temperature $\left(25^{\circ} \mathrm{C}\right)$ for 96 hours, plants then chopped and ground into powder. The garden rocket seeds were obtained from local market (local cultivar).

\subsection{Pot experiment}

A pot experiment was set in plastic pots $(18 \times 35 \mathrm{~cm})$ and arranged in completely randomized design (CRD) with four replicates. Five treatments were used, the first one $\mathrm{T}_{1}$ represented the control, where the pot was free from Amaranthus powder (0), the other four treatments represented by $\mathrm{T}_{2}, \mathrm{~T}_{3}, \mathrm{~T}_{4}$ and $\mathrm{T}_{5}$, the soil in the pots were incorporated with Amaranthus viridis powder 10, 20, 30 and $40 \mathrm{~g}$ per pot representing $0.5,1.0,1.5$ and $2.0 \%(\mathrm{w} / \mathrm{w})$ respectively. Ten seeds of garden rocket were sown in each pot and later thinned to two seedlings. Pots were irrigated daily with tap water. During the experiment plant height, number of leaves, leaf area, shoot and root fresh and dry weight were recorded and chlorophyll content $(\mathrm{a}, \mathrm{b})$ and some elements $(\mathrm{P}, \mathrm{Ca}, \mathrm{Mg}, \mathrm{Fe})$ were determined. The data of the experiment were subjected to analysis of variance (ANOVA) according to [5].

\section{Results and discussion}

The germination percentage showed a significant decrease $(\mathrm{P}=0.05)$ in all treatments as compared to control (Table 1$)$. The germination percentage decreased from $96.67 \%$ (control) to $60,20,16$ and $3.33 \%$ at treatments $\mathrm{T}_{2}, \mathrm{~T}_{3}, \mathrm{~T}_{4}$ and $\mathrm{T}_{5}$ respectively. These results were supported by the result of [2] who found that Amaranthus species extract concentrations inhibited the germination of Lettuce seeds. Similar results were reported by Kalinova et al. [6] who reported that Amaranthus hybridus extract inhibited the germination of soybean, pea and Vetch. In this respect [7] reported that allelopathic effects of Amaranthus viridsi decreased germination percentage of rye grass compared to control.

The inhibition of germination of garden rocket may be attributed to the presence of phynolic compounds in Amaranthus viridis which affected and inhibited the garden rocket germination.

Table 1 Allelopathic effect of Amaranthus viridis powder on germination, plant height, number of leaves and leaf area of garden rocket (Eruca sativa)

\begin{tabular}{|l|c|c|c|c|}
\hline \multicolumn{1}{|c|}{ Treatments } & $\begin{array}{c}\text { Germination } \\
\mathbf{( \% )}\end{array}$ & $\begin{array}{c}\text { Plant } \\
\text { height } \mathbf{( c m )}\end{array}$ & $\begin{array}{c}\text { Number of } \\
\text { leaves }\end{array}$ & $\begin{array}{c}\text { Leaf area } \\
\text { (cm } \mathbf{c m}^{2}\end{array}$ \\
\hline $\mathrm{T}_{1}($ control) & 96.67 & 11.00 & 3.90 & 8.29 \\
\hline $\mathrm{T}_{2}(0.5 \% \mathrm{w} / \mathrm{w})$ & 60.00 & 10.00 & 3.80 & 8.20 \\
\hline $\mathrm{T}_{3}(1.0 \% \mathrm{w} / \mathrm{w})$ & 20.00 & 8.00 & 3.60 & 8.16 \\
\hline $\mathrm{T}_{4}(1.5 \% \mathrm{w} / \mathrm{w})$ & 16.67 & 8.00 & 3.43 & 8.14 \\
\hline $\mathrm{T}_{5}(2.0 \% \mathrm{w} / \mathrm{w})$ & 3.33 & 6.00 & 3.40 & 0.18 \\
\hline $\mathrm{LSD}$ & 4.94 & 0.78 & 0.05 & 0.08 \\
\hline
\end{tabular}

The plant height decreased from $11 \mathrm{~cm}$ at control to $10.00,8.00,8.00$ and $6.00 \mathrm{~cm}$ at treatments $\mathrm{T}_{2}, \mathrm{~T}_{3}, \mathrm{~T}_{4}$ and $\mathrm{T}_{5}$ respectively. In this respect [8] found that Amaranthus viridis incorporated powder significantly decreased plant height of sorghum, millet, maize and wheat.

The number of leaves and leaf area of garden rocket exhibited significant different $(\mathrm{P}=0.05)$ between treatments as compared with control (Table 1). These results are in agreement with the findings of [2] who found that Amaranthus species significantly reduced the seedlings development of lettuce. These results were supported by the results of [8] who found that Amaranthus viridis powder decreased the number of leaves of some poaceous crops. 
The shoot fresh and dry weight of garden rocket expressed significant decrease in treatments as compared with control (Table 2). These results were supported by the results of [6] who reported that Amaranthus hybrids when added as dry ground material decreased the dry weight of the shoot and root of red clover and root of alfalfa. In this respect [9] reported that a production in dry mass of Chenopoctium album, Melilotus alba and Nicotiana plumbaginifolta treated with Cassia sophera.

The root length, root fresh and dry weight showed significant decrease in treatments as compared with control (Table 2). Similar results were reported by [ 8] who found a decrease in root length as well as root fresh and dry weight of sorghum, millet, maize and wheat when Amaranthus viridis powder incorporated into the soil.

The chlorophyll a and $b$ decreased as the concentration of Amaranthus increased (Table 3). In this respect [10] showed that total chlorophyll content of maize and kidney bean were reduced due to the application of Eucalyptus leaf leachates. Similar results were reported by [11] who found a reduction in chlorophyll a content of corn treated with Eucalyptus rostrata leaf residue.

Table 2 Allelopathic effect of Amaranthus viridis powder on shoot fresh and dry weight, root length, root fresh and dry weight of garden rocket (Eruca sativa)

\begin{tabular}{|l|c|c|c|c|c|}
\hline \multicolumn{1}{|c|}{ Treatments } & $\begin{array}{c}\text { Shoot fresh } \\
\text { weight } \\
\text { (g) }\end{array}$ & $\begin{array}{c}\text { Shoot dry } \\
\text { weight } \\
\text { (g) }\end{array}$ & $\begin{array}{c}\text { Root } \\
\text { length } \\
\text { (cm) }\end{array}$ & $\begin{array}{c}\text { Root fresh } \\
\text { weight } \\
\text { (g) }\end{array}$ & $\begin{array}{c}\text { Root dry } \\
\text { weight } \\
\text { (g) }\end{array}$ \\
\hline $\mathrm{T}_{1}(\mathrm{control})$ & 4.55 & 1.27 & 5.70 & 0.37 & 0.05 \\
\hline $\mathrm{T}_{2}(0.5 \% \mathrm{w} / \mathrm{w})$ & 3.60 & 0.95 & 4.60 & 0.30 & 0.04 \\
\hline $\mathrm{T}_{3}(1.0 \% \mathrm{w} / \mathrm{w})$ & 3.40 & 0.82 & 4.40 & 0.28 & 0.03 \\
\hline $\mathrm{T}_{4}(1.5 \% \mathrm{w} / \mathrm{w})$ & 3.33 & 0.80 & 4.20 & 0.20 & 0.02 \\
\hline $\mathrm{T}_{5}(2.0 \% \mathrm{w} / \mathrm{w})$ & 3.30 & 0.73 & 3.80 & 0.18 & 0.01 \\
\hline $\mathrm{LSD}$ & 0.00 & 0.00 & 0.10 & 0.00 & 0.00 \\
\hline
\end{tabular}

Table 3 Allelopathic effect of Amaranthus visridis powder on chlorophyll content and some chemical elements of garden rocket (Eruca sativa)

\begin{tabular}{|c|c|c|c|c|c|c|}
\hline \multirow{2}{*}{ Treatments } & \multicolumn{2}{|c|}{ Chlorophyll } & \multirow{2}{*}{ P (mg/kg) } & \multirow{2}{*}{$\begin{array}{c}\mathrm{Ca} \\
(\mathrm{mg} / \mathrm{kg})\end{array}$} & \multirow{2}{*}{ Mg (mg/kg) } & \multirow{2}{*}{$\begin{array}{c}\text { Fe } \\
\text { (mg/kg) }\end{array}$} \\
\hline & a (mg/g) & b (mg/g) & & & & \\
\hline $\mathrm{T}_{1}$ (control) & 554.80 & 275.39 & 118 & 3800 & 1200 & 1443 \\
\hline $\mathrm{T}_{2}(0.5 \% \mathrm{w} / \mathrm{w})$ & 483.20 & 227.02 & 105 & 3000 & 1200 & 1338 \\
\hline $\mathrm{T}_{3}(1.0 \% \mathrm{w} / \mathrm{w})$ & 509.11 & 269.36 & 115 & 3000 & 1160 & 1361 \\
\hline $\mathrm{T}_{4}(1.5 \% \mathrm{w} / \mathrm{w})$ & 508.61 & 182.45 & 113 & 3000 & 240 & 1107 \\
\hline $\mathrm{T}_{5}(2.0 \% \mathrm{w} / \mathrm{w})$ & 445.57 & 256.59 & 112 & 3000 & 1146 & 1218 \\
\hline LSD & 4.79 & 4.99 & 3.80 & 9.24 & 3.23 & 3.80 \\
\hline
\end{tabular}

The content of phosphorous $\mathrm{P}$, calcium $\mathrm{Ca}$, magnesium $\mathrm{Mg}$ and iron Fe decreased significantly as the garden rocket growing in soil incorporated with Amaranthus viridis powder. Similar results were reported by [11] who found that Eucalyptus allelochemicals reduced the amount of $\mathrm{P}$ and $\mathrm{N}$. The results were in agreement with the results of [12] who observed that root exudates of cucumber inhibited the uptake of $\mathrm{K}^{+}, \mathrm{Ca}^{2+}, \mathrm{Mg}^{2+}$ and $\mathrm{Fe}^{2+}$ by cucumber seedlings. Also the work of [13] who showed that excretion of roots can inhibit the roots of absorbs ions.

It is worth mentioning that the suppression in the growth of garden rocket may be attributed to the decrease in shoot and root length of the seedlings which was induced by the allelochemicals found in Amaranthus virids. These phytochemicals may decrease water and nutrient absorption and consequently affect the whole growth. 


\section{Conclusion}

From this study it was concluded that Amaranthus viridis affected the germination and growth of garden rocket negatively and reduced the yield, large scale experiments are required to evaluate the negative effect of Amaranthus viridis under field conditions.

\section{Compliance with ethical standards}

\section{Acknowledgments}

Authors would like to thanks Department of Biology, Faculty of Education, Alzaiem Alazhari University for the assistance during this study.

\section{Disclosure of conflict of interest}

The authors have declared that no competing interests exist.

\section{References}

[1] Awan FK, Rasheed, M, Ashraf M, Khurshid MY. Efficacy of brassica, sorghum and sunflower aqueous extracts to control wheat weeds under rainfed conditions of Pothwar, Pakistan, The Journal of Animal \& Plant Sciences. 2012; 22(3): 715-721.

[2] Sausa Carvalho, Marcos Schheiden, Lerissa Fousela, Andrade-Vieirg, Fabio Eduardodos Santos, Felipe Folgaroli Corre, Maria das Gracas Cardoso, Luciane Resende Vilel . Allelopathic potential and phytochemical screening of ethanolic extracts from five species of Amaranthus spp. in the plant model Leduca sativa, Scientia Horticulturae. 2019; 245: 90-98.

[3] Thomson CA, Rock CL, Caan BJ, Flatt SW, Al0Delaimy WA, Newman VA, Hajek RA, Chilton JA, Pierce JP. Increase in cruciferous vegetable intake in women previously treated for breast cancer participating in a dietary intervention trial. Nutr. Cancer. 2007; 57: 11-19.

[4] Holm LG, Plucknett DL, Pancho JV, Herberger JP. The worlds worst weeds: Distribution and Biology. Malabar, FL: University Press of Hawaii. 1977.

[5] Gomez AK, Gomez AA. Statistical procedures for agricultural research,Canada, John Willey and Sons, Inc. 1984.

[6] Kalinova S, Golubinova I, Hristoskov A, Ilieva A. Allelopathic effect of aquaeous extract from root systems of Johnson grass on seed germination and initial development of soybean, pea and Vetch. Rotar. Pourt. 2012; 49: 250-256.

[7] Shamima Sultana, Asaduzzaman M. Allelopathic potential of Amarantus viridis L. against annual ryegrass. Developing solutions to evolving weed problem. 18th Australasian Weeds Conference, Melbourne, Victoria, Australia. 8-11 October 2012; 181-183.

[8] Dafaallah AB, Abdelrahman A0, Yousif MH. Allelopathic effect of pigweed (Amaranthus viridis L.) on seed germination and seed growth of some poaceous crop. U. of Bakt Alruda Scientific Journal. April $2017 ; 20$.

[9] Gulzar A, Siddiqui MB, Shaziabi. Assessment of allelopathic potential of Cassia sophera |L. on seedling growth and physiological basis of weed plants. African Journal of Biotechnology. 2014; 13(9): 1037-1046.

[10] El-Khawas SA, Shehata MM. The allelopathic potentialities of Acacia nilotica and Eucalyptus rostrata on monocot (Zea maysc) and Dicot (Phaseolus vulgaris L.) plants. Biotechnology. 2005; 4(1): 23-34.

[11] Hegab MM, Gabr MA, Al-Wakeel SAM, Hamed BA. Allelopathic potential of Eucalyptus rostrata leaf residue on some metabolic activities of Zea mays L., Universal J. of Plant Science. 2016; 4(2): 11-21.

[12] Yu JQ, Matsui Y. Effects of root exudates of cucumber (Cucumis sativus) and allelochemical on uptake by cucumber seedlings. J. Chem. Ecol. 1997; 23: 817-829.

[13] Li ST, Zhou JM, Wang HY, Cheu XQ. Research surveys of allelopathy in plants. Chin. J. Eco. Agric. 2002; 10: 72-74. 